Environmental Research Journal 12 (2-4): 6-11, 2018

ISSN: 1994-5396

(C) Medwell Journals, 2018

\title{
Airlift Bubble Column Electrocoagulation Treatment Process for Carwash Wastewater
}

\author{
Israa Mawlood Atiyah and Basma Abbas Abdul-Majeed \\ College of Engineering, University of Baghdad, Baghdad, Iraq
}

\begin{abstract}
Large quantity of carwash wastewater is produced per day from carwash stations. It widely contains a significant quantity of oil and grease, suspended solids, heavy metals and organics, along with chemicals from detergents. Electrocoagulation with new configuration was investigated to remove COD, turbidity, Total Dissolved Solids (TDS) from wastewater and reduce its Electrical Conductivity (EC), so, it can be valid for reuse. Aluminum foil thin layer is used as an electrode in this treatment process. The effects of air flow at different voltage and treatment time were studied. The best result was found at $30 \mathrm{~V}$ and $5 \mathrm{~L} / \mathrm{min}$ at treatment time $90 \mathrm{~min}$ where the removal efficiencies of COD, turbidity and TDS were $96.99,99.87$ and 20.59\%, respectively and reduced electrical conductivity to $683.594 \mu \mathrm{S} / \mathrm{cm}$.
\end{abstract}

$\underline{\text { Key words: Electrical conductivity, total dissolved solids, COD, turbidity, aluminum foil, chemicals }}$

\section{INTRODUCTION}

A carwash station is considered as a non-household establishment to clean outside and inside of the engine vehicles. The car-washing procedure comprises at least of two stages: High-pressure water is utilized to evacuate soil particles in the initial step which is called the tidy cleaning step. In the last step, degreasing agent is showered over the auto body. The degreasing agent solubilizes the contaminations and expels them from the auto body (Boussu et al., 2007; Karakulski and Morawski, 2003).

After 2003, Iraq had experienced a significant increase in the number of cars with 5.8 million cars distributed between governorates according to the Central Statistics Organization of the Ministry of Planning. Baghdad ranked first in the number of cars with 2.1 million cars while Irbil ranked second with 617 thousand cars followed by Basra with 289 thousand cars. Specialists confirm that the cars cause significant damages to the environment.

Wastewater from carwash station may contain the following contaminants (Abdel-Magid et al., 2000; Baddour, 2012; Anonymous, 1995; Hajjar and Farhoud, 2012).

Phosphorus and nitrogen: these may cause some growth of troublesome plants in water pools; Oils and greases: these include dangerous and toxic substances such as benzene, lead, zinc, chromium, arsenic, cadmium and nitrate. Also, other metals such as copper resulting from auto brake can be found; Chemicals and oils: these are used in the processes of maintenance and cleaning machines; Chemicals such as, hydrofluoric acid and ammonium bifluoride products and solvent-base solvents which are considered harmful to living organisms; Surface active substances: these are contained in detergents and have the ability to reduce the surface tension of water. By this washing the dirt and greases from the cars. Also they are considered toxic materials; The dirt suspended in water inlets and bar screens. These may prevent the discharge of water into sewers.

In the past, people utilized the backyards of their home to wash their cars. Now a days, car-washing stations are used to wash cars. The car-washing process needs a significant quantity of fresh water to remove the contaminants successfully (Gonder et al., 2017).

Electrocoagulation (EC) is a sophisticated process including many chemical and physical phenomena. It uses sacrificial electrodes to supply ions into the wastewater (Liu et al., 2010). In the EC process, the coagulants are generated in situ by dissolving electrically the consumable electrodes. The metal ions generation occurs at the anode while the hydrogen gas is released at the cathode (Wang et al., 2007). In the solution, the metal cations $\left(\mathrm{Al}^{+3}\right)$ produced from the anode oxidation combine with hydroxyl ion $\left(\mathrm{OH}^{-}\right)$resulting from water to form highly charged coagulant $\mathrm{Al}(\mathrm{OH})_{3}$.

$\mathrm{EC}$ process has several benefits such as no chemical requirements, more stable and decreased the amount of sludge, simple equipment and easy operation as well as low operating costs (Chen, 2004; Behbahani et al., 2011; Fajardo et al., 2015).

Corresponding Author: Israa Mawlood Atiyah, College of Engineering, University of Bahdad, Baghdad, Iraq 
The difficulty with these processes is the contact of coagulants $\mathrm{Al}(\mathrm{OH})_{3}$ with the suspended particles. To increase this contact a process of mixing can be used. A mechanical mixer is used inside the container. By this method, the mixing is increased. This consumes a large amount of energy and by this the operational cost is increased (Ammar and Akbar, 2018).

Airlift reactor is a special case of bubble column. It is formed of two distinguished zones, the riser and the downcomer. The air may be injected in the riser zone which creates a difference in gas holdup between the riser and downcomer. Due to the gas holdup difference and thus, densities differences between these zones there will be a static pressure difference between the riser and downcomer, this leads the liquid to circulate between them (Chisti, 1989). The driving force of the overall liquid circulation in airlift reactor comes from the difference in gas holdup between the riser zone and the downcomer zone which leads to a difference in densities. There are two configurations for airlift: internal loop and external loop airlift reactor (Di Felice, 2005).

The aim of this research is to treat carwash wastewater before being discharged to the surrounding using the airlift technique. The effect of some parameters such as air flow rate at different voltages and treatment time on the removal efficiency of $\mathrm{COD}$, turbidity, electrical conductivity and Total Dissolved Solids (TDS) in wastewater were investigated.

\section{MATERIALS AND METHODS}

Characteristics of carwash wastewater: Carwash wastewater used in present study was collected from carwash stations in Baghdad, Iraq. Physical and chemical characteristics of carwash wastewater are measured in the Chemical Engineering Laboratory in the University of Baghdad, all the properties are illustrated in Table 1.

Experimental set up and work: A particularly interesting area of this research is the use of a new electrode with a new configuration for the electrochemical cell to treat carwash wastewater. Thin film electrode was used in the treatment is aluminum foil where its thickness is $<0.2 \mathrm{~mm}$ and may sometimes reach a thickness of $6 \mu \mathrm{m}$ (Berger, 2002; Said and MikeC, 2011).
These sheets of foil are very flexible and can be easily bent and formed and used as electrodes in the electrocoagulation process because it has the ability to dissolve electrochemically by oxidation.

The use of aluminum foil as electrodes creates the differences in the field of traditional electrocoagulation systems. This thin film electrode is considered as an innovative method for maintaining efficiency and flow consistency through the use of non-scaling, sacrificial electrode technology that eliminates passivation. This thin electrode has multi-benefits: low capital costs, inexpensive to operate, low power requirements no chemicals required, treatment of multiple contaminants, and fewer and thinner layer reduce weight.

The experiments were performed in a cylindrical Perspex glass airlift flotation column with the dimensions (14 cm I.D and $24 \mathrm{~cm}$ in height) with two air distributor made of porous material with $1.5 \mathrm{~cm}$ diameter and $2.5 \mathrm{~cm}$ height as shown in Fig. 1. It operated in a semi-batch mode (batch wastewater, continuous air). Two tapes of aluminum foil with $22 \mathrm{~cm}$ long, $5 \mathrm{~cm}$ high and $0.1 \mathrm{~mm}$ thickness were rolled in a cylindrical shape with $3 \mathrm{~cm}$ diameter. These were used as electrodes (anode and cathode). The electrodes were placed in a way that the air distributor is in the center of the cylindrical electrodes. The use of aluminum foil as electrodes in the EC process contributes to the contaminant removal without any addition of chemicals or varying the $\mathrm{pH}$, consequently it is effective and environmentally friendly (Barrera-Diaz et al., 2014).

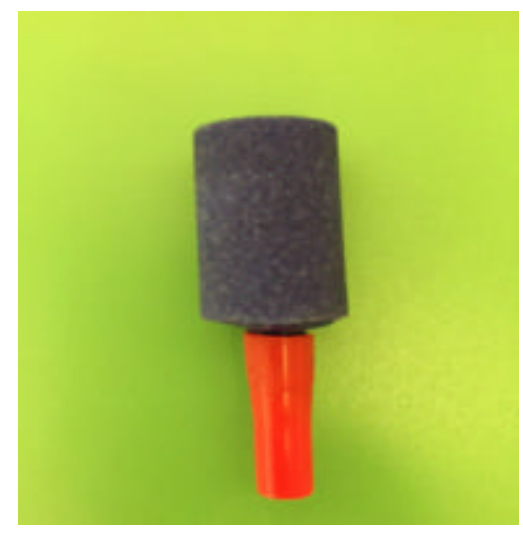

Fig. 1: Porous air distributor

Table 1: Physical and chemical properties of carwash wastewater

\begin{tabular}{lll}
\hline Analysis tests & Values/Units & Device used \\
pH & $7.2-8(\mathrm{Nil})$ & pH meter-ATC \\
Turbidity & $227(\mathrm{NTU})$ & Turbi Direct Lovibond,TB 300 IR, Germany \\
Total Dissolved Solid (TDS) & $403(\mathrm{mg} / \mathrm{L})$ & TDS meter (hold) TDS-3 \\
Electrical Conductivity (EC) & $792.612(\mu \mathrm{S} / \mathrm{cm})$ & Senso Direct Oxi 200 Lovibond \\
Chemical Oxygen Demand (COD) & $632(\mathrm{mg} / \mathrm{L})$ & Lovibond MD 200, Germany \\
Oil content & $105(\mathrm{mg} / \mathrm{L})$ & Handheld Oil-in-Water meter \\
\hline
\end{tabular}




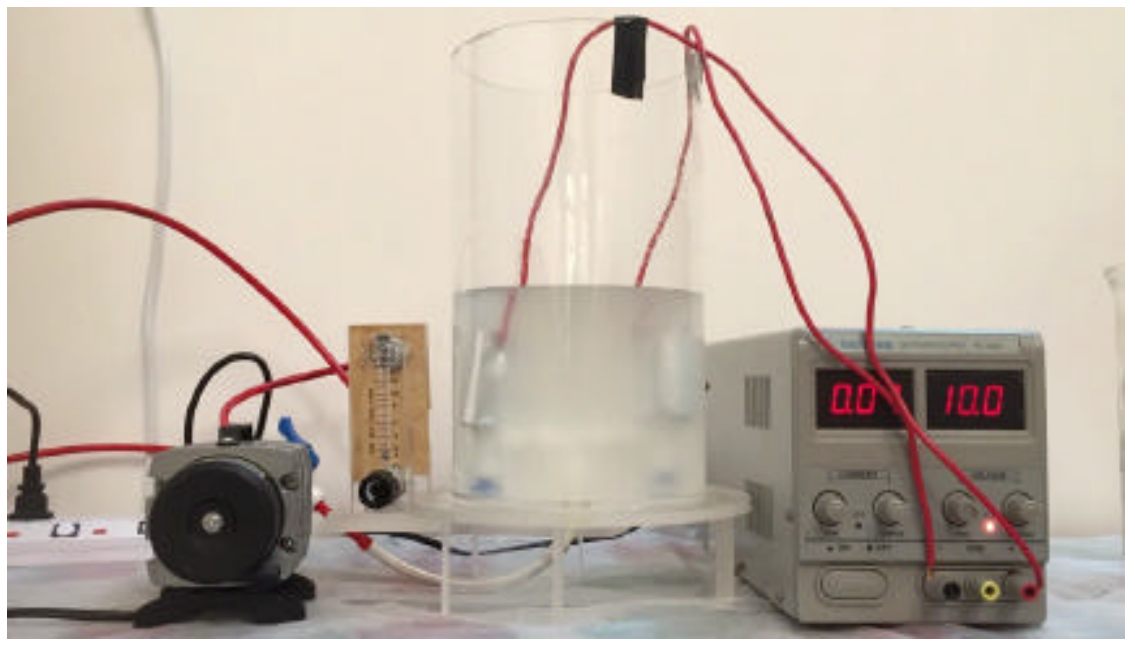

Fig. 2: Arrangement of electrocoagulation cell

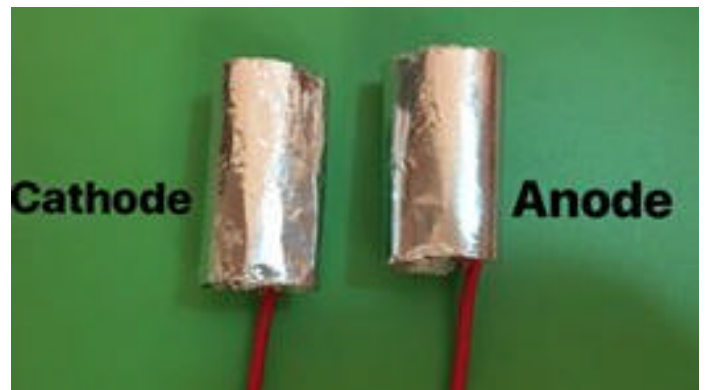

Fig. 3: Aluminum foil electrodes

The experiment apparatus is shown photographically in Fig. 2. Figure 3 shows the aluminum foil electrodes. Electrochemical cell shown in the Fig. 2 consists of DC Power Supply (PS-305D) air pump model ACO-001 and air flow meter. The distance between the two distributors is $5 \mathrm{~cm}$. The $1800 \mathrm{~mL}$ of wastewater was treated in this process without adjustment of $\mathrm{pH}$.

\section{RESULTS AND DISCUSSION}

Effect of air flow rate and different voltages: Three air flow rates $(1.5,3$ and $5 \mathrm{~L} / \mathrm{min})$ with three voltages $(10,20$ and $30 \mathrm{~V}$ ) were applied to examine the effect of air flow rate and the voltage on the airlift bubble column electrocoagulation treatment of carwash wastewater. The effect of air flow rate and the voltage on COD, turbidity, EC and TDS is illustrated in Fig. 3-5. The result shows an increase in the removal efficiency by increasing the applied voltage and air flow rate.

The high air flow rate produced a good mixing by airlift system where the riser carries the ions which were produced during oxidation and reduction process and the

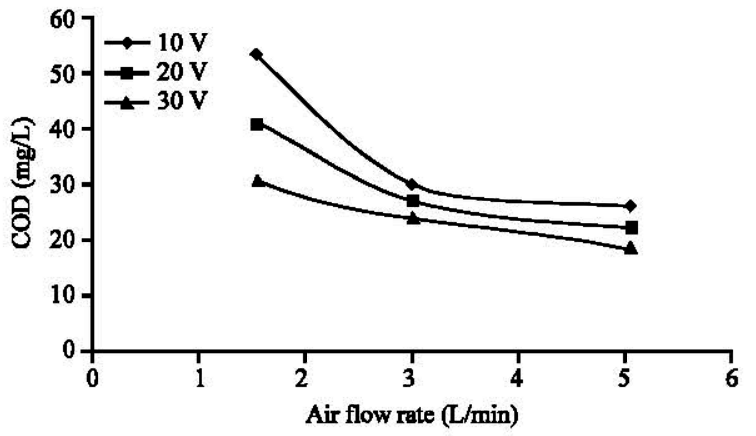

Fig. 4: Effect of air flow rate at the different voltage on COD; Initial COD: $632 \mathrm{mg} / \mathrm{L}$

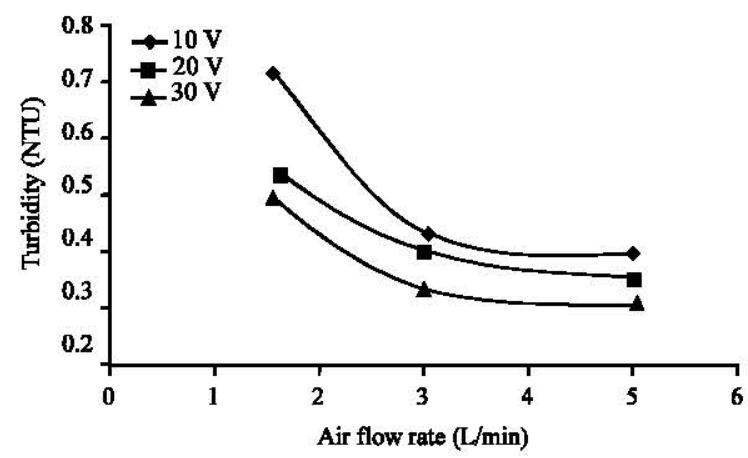

Fig. 5: Effect of air flow rate at the different voltage on turbidity; Initial turbidity: 227 NTU

downcomer get down these ions. These circulations of the riser and downcomer provide perfect contact between the ions in water to produce coagulant and precipitate.

The increase of air flow rate increased the speed of the bubbles which carry the ions and therefore the contact between ions occurs at less time. 
Effect of air flow rate and the different voltage on COD removal: The removal efficiency of COD at $10 \mathrm{~V}$ and $(1.5$, 3 and $5 \mathrm{~L} / \mathrm{min}$ ) air flow rate was $(91.61,95.25$ and $95.88 \%)$, respectively. These were with residual COD as $(53,30$ and $26 \mathrm{mg} / \mathrm{L})$, respectively. For $20 \mathrm{~V}$ and air flow rate $(1.5,3$ and $5 \mathrm{~L} / \mathrm{min}$ ), respectively, the removal efficiency of COD was $(93.51,95.73$ and $96.52 \%)$ and the residual were $(41,27$ and $22 \mathrm{mg} / \mathrm{L})$, respectively. Finally, for $30 \mathrm{~V}$ and air flow rate $(1.5,3$ and $5 \mathrm{~L} / \mathrm{min})$ respectively, the removal efficiency of COD was $(95.09,96.2$ and $96.99 \%)$ and the residual were $(31,24$ and $19 \mathrm{mg} / \mathrm{L})$. It has been found that the best value is for COD removal efficiency was $96.99 \%$ where the voltage $30 \mathrm{~V}$ and air flow rate of $5 \mathrm{~L} / \mathrm{min}$. These results are shown clearly in Fig. 4.

Aluminum foil thin film electrodes show higher removal efficiencies of COD when increasing the voltage. This attributable to the oxidation of aluminum has one state $\left(\mathrm{Al}^{+3}\right)$ so, more amount of $\left(\mathrm{Al}^{+3}\right)$ produced in solution, thus, an organic compound exist in wastewater it will react almost completely with $\mathrm{Al}^{+3}$ and produced an insoluble compound which is easily removed by sedimentation or flotation.

Effect of air flow rate and the different voltage on turbidity removal: The removal efficiencies of turbidity at $10 \mathrm{~V}$ and $(1.5,3$ and $5 \mathrm{~L} / \mathrm{min})$ air flow rate were respectively, $(99.67,99.81$ and $99.83 \%)$ and the residual turbidity in this case was $(0.73,0.43$ and 0.39 NTU), respectively. For $20 \mathrm{~V}$ and air flow rate $(1.5,3$ and $5 \mathrm{~L} / \mathrm{min})$, respectively, the removal efficiencies of turbidity were $(99.76,99.82$ and $99.85 \%)$ and the residuals were $(0.54,0.4$ and $0.35 \mathrm{NTU})$. Finally, for $30 \mathrm{~V}$ and air flow rate $(1.5,3$ and $5 \mathrm{~L} / \mathrm{min}$ ), respectively, the removal efficiencies of turbidity were $(95.09,99.85$ and $99.87 \%)$ and the residuals were $(0.49,0.33$ and $0.3 \mathrm{NTU})$, respectively. The best value is where the voltage was $30 \mathrm{~V}$ and air flow rate was $5 \mathrm{~L} / \mathrm{min}$ which gave a removal efficiency of turbidity equals $99.87 \%$. Figure 5 shows these results clearly.

The anodic dissolution rate of aluminum foil electrode or film electrode is increased at a voltage over $10 \mathrm{~V}$, thus, producing a large amount of both coagulant and precipitant. As a result, high turbidity removal was achieved.

Effect of air flow rate and the different voltage on TDS removal: The removal efficiencies of TDS at $10 \mathrm{~V}$ and $(1.5$, 3 and $5 \mathrm{~L} / \mathrm{min}$ ) air flow rate were respectively $(13.39,14.14$ and $14.89 \%)$ and the residual TDS were $(349,346$ and 343 $\mathrm{mg} / \mathrm{L})$, respectively. For $20 \mathrm{~V}$ and air flow rate of $(1.5,3$ and $5 \mathrm{~L} / \mathrm{min}$ ), respectively, the removal efficiencies of TDS were $(17.87,18.36$ and $20.59 \%)$ and the residuals were (331, 329 and $322 \mathrm{mg} / \mathrm{L})$. Finally, for $30 \mathrm{~V}$ and air flow rate (1.5,

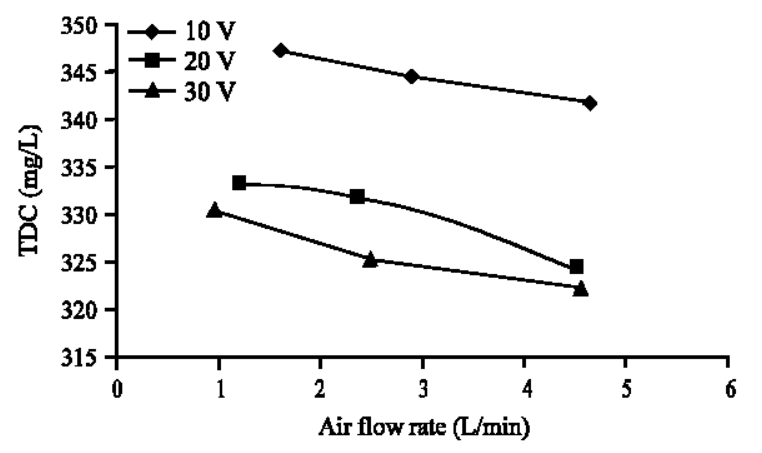

Fig. 6: Effect of air flow rate at the different voltage on TDS; Initial TDS: $403 \mathrm{mg} / \mathrm{L}$

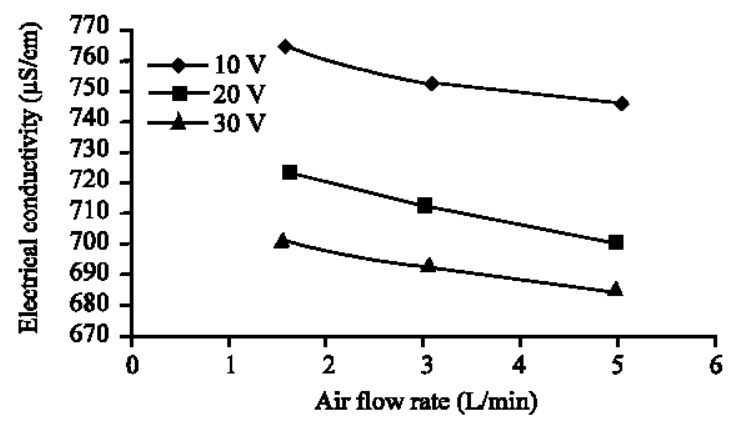

Fig. 7: Effect of air flow rate at the different voltage on EC; Initial EC: $792.612 \mu \mathrm{S} / \mathrm{cm}$

3 and $5 \mathrm{~L} / \mathrm{min}$ ), respectively, the removal efficiency of TDS was $(18.61,19.85$ and $20.59 \%$ ) and the residuals were $(328,323$ and $320 \mathrm{mg} / \mathrm{L})$. The best result is found at $30 \mathrm{~V}$ and $5 \mathrm{~L} / \mathrm{min}$ where the removal efficiency was $20.59 \%$. Figure 6 shows the results of TDS removal with the air flow rate at different voltage.

Effect of air flow rate and the different voltage on reduced electrical conductivity: Different ionic species are involved in carwash wastewater which is increases the electrical conductivity of carwash wastewater. The initial electrical conductivity was $792.612 \mu \mathrm{S} / \mathrm{cm}$ and this value is decreased when increase the voltage due to the removal of ionic species by electrocoagulation.

Electrical conductivity at $10 \mathrm{~V}$ and $(1.5,3,5 \mathrm{~L} / \mathrm{min})$ air flow rate were respectively $(764.475,751.998,745.256$ $\mu \mathrm{S} / \mathrm{cm})$. For $20 \mathrm{~V}$ and $(1.5,3,5 \mathrm{~L} / \mathrm{min})$ air flow rate were respectively $(723.949,710.986,699.046 \mu \mathrm{S} / \mathrm{cm})$. For $30 \mathrm{~V}$ and $(1.5,3,5 \mathrm{~L} / \mathrm{min})$ air flow rate were respectively, $(700.874,691.311,683.594 \mu \mathrm{S} / \mathrm{cm})$. The best result is found at $30 \mathrm{~V}$ and $5 \mathrm{~L} / \mathrm{min}$ where the reduced electrical conductivity was $683.594 \mu \mathrm{S} / \mathrm{cm}$. Figure 7 show the effect of air flow rate at different applied voltage on electrical conductivity. 


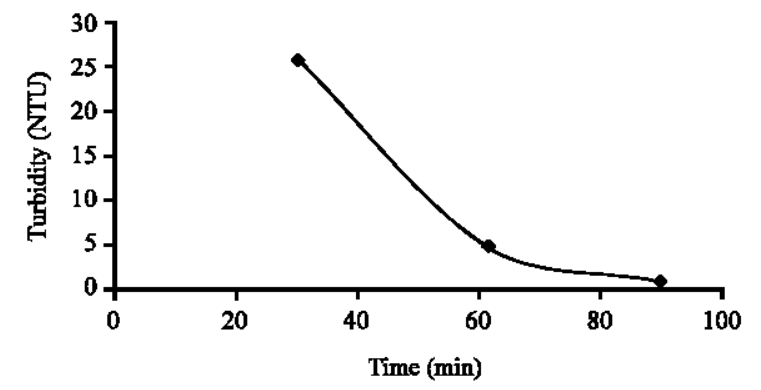

Fig. 8: Effect of time on COD removal at constant voltage: $30 \mathrm{~V}$ and air flow rate: $5 \mathrm{~m} \mathrm{~L} / \mathrm{min}$; Initial COD: 632 $\mathrm{mg} / \mathrm{L}$

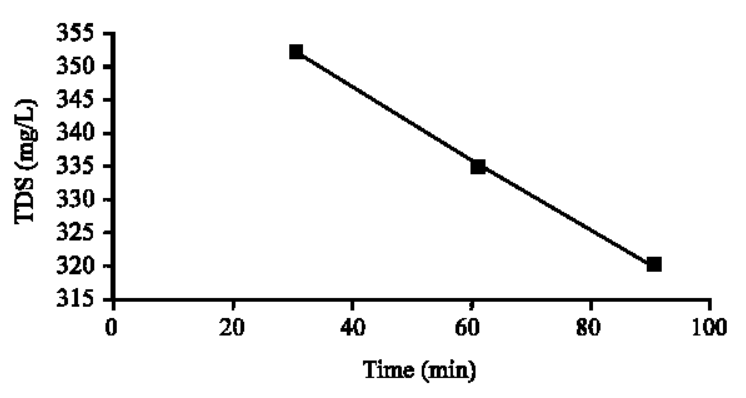

Fig. 9: Effect of time on turbidity removal at constant voltage: $30 \mathrm{~V}$ and air flow rate: $5 \mathrm{~L} / \mathrm{min}$; Initial turbidity: $227 \mathrm{NTU}$

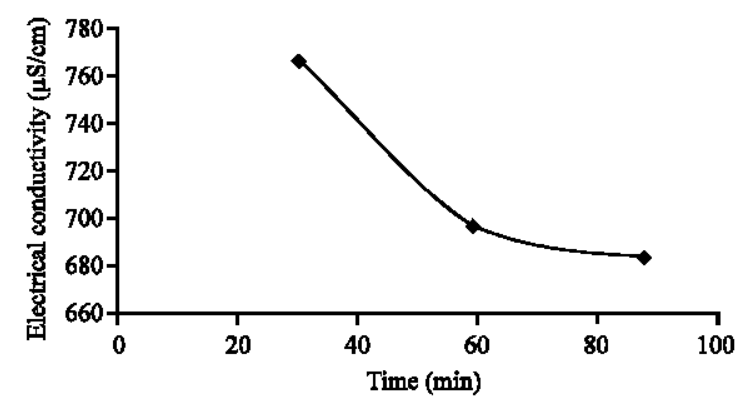

Fig. 10: Effect of time on TDS removal at constant voltage: $30 \mathrm{~V}$ and air flow rate; Initial TDS: 403 $\mathrm{mg} / \mathrm{L}$

Effect of treatment time: Three treatment times $(30,60$ and $90 \mathrm{~min}$ ) were used to examine its effect on electrocoagulation using thin film electrode. The results are illustrated in Fig. 8-11.

The removal efficiency of $\mathrm{COD}$ at 30,60 and 90 min was respectively $(83.23,94.78$ and $96.99 \%)$ with residuals of $(106,33$ and $19 \mathrm{mg} / \mathrm{L})$. Figure 8 shows these results.

The removal efficiency of turbidity at 30,60 and 90 min was respectively $(87.27,97.75$ and $99.86 \%)$ and

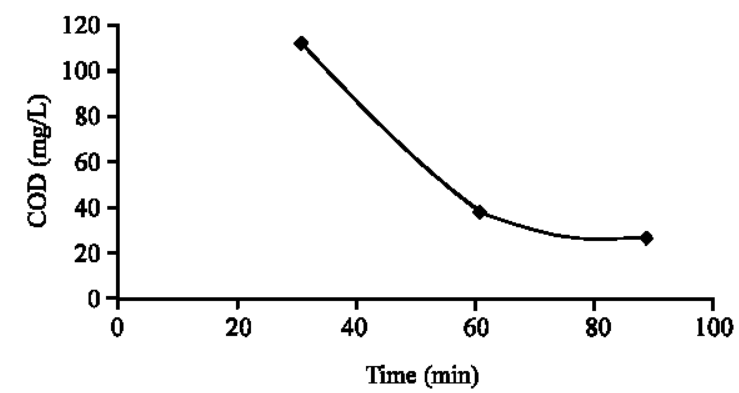

Fig. 11:Effect of time on EC removal at constant voltage: $30 \mathrm{~V}$ and air flow rate: $5 \mathrm{~L} / \mathrm{min}$; Initial EC: 792.612 $\mu \mathrm{S} / \mathrm{L}$

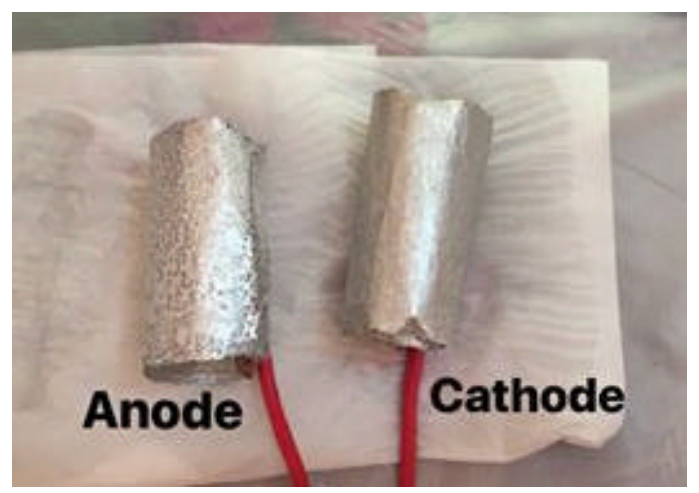

Fig. 12: Anode and cathode after the treatment process

the residuals were $(28.9,5.1$ and $0.3 \mathrm{NTU})$. These results are shown in Fig. 9. The removal efficiency of TDS at 30, 60 and $90 \mathrm{~min}$ was respectively $(12.66,16.87$ and $20.59 \%)$ and the residuals were $(352,335$ and $320 \mathrm{mg} / \mathrm{L})$. Figure 10 shows these results.

Electrical conductivity reduced from the initial value $792.612 \mu \mathrm{S} / \mathrm{cm}$ to $(775.113,698.996,683.594 \mu \mathrm{S} / \mathrm{cm})$ at $(30,60,90 \mathrm{~min})$, respectively. Figure 11 show this result.

The best result is found at the treatment time of $90 \mathrm{~min}$ because the number of ions produced and hydrolyzed to form $\mathrm{Al}(\mathrm{OH})_{3}$ is higher than that at 30 and $60 \mathrm{~min}$. Most of the thin film layer of aluminum foil is dissolved at first $30 \mathrm{~min}$ and the remainder completed the dissolution at 60 and $90 \mathrm{~min}$ to produce coagulant. Figure 12 shows the aluminum foil electrodes after the treatment process, where it can be seen that this foil cannot be used for the second time.

\section{CONCLUSION}

In airlift bubble column electrocoagulation method, using different voltage $(10,20$ and $30 \mathrm{~V})$ with different air flow rate $(1.5,3$ and $5 \mathrm{~L} / \mathrm{min})$ were investigated as a new 
experiment. It is found that the best voltage and air flow rate to achieve high removal efficiencies is $30 \mathrm{~V}$ and $5 \mathrm{~L} / \mathrm{min}$, respectively. The time needed to remove COD, turbidity, TDS and decrease electrical conductivity from $(632-19 \mathrm{mg} / \mathrm{L})(227-0.3 \mathrm{NTU})(403-320 \mathrm{mg} / \mathrm{L})$ and (792.612-683.594 $\mu \mathrm{S})$, respectively is $90 \mathrm{~min}$. Aluminum foils thin film electrode can be used for once.

\section{REFERENCES}

Abdel-Magid, I.M., A.A. Abdel-Rahman, M.T. Darderi and A.I. AlTijani, 2000. Wastewater. Sudan University Printing Publishing and Distribution House, Khartoum State, Sudan,

Ammar, S.H. and A.S. Akbar, 2018. Oilfield produced water treatment in internal-loop airlift reactor using electrocoagulation/flotation technique. Chin. J. Chem. Eng., 26: 879-885.

Anonymous, 1995. Federal register part XIV: Final national pollutant discharge elimination system storm water multi-sector general permit for industrial activities notice. Environmental Protection Agency (EPA), Washington, USA.

Baddour, M.I., 2012. Treatment Plants Book (1): Institutes of Technological Engineering and Institutes of Technical Auditors. Ministry of Higher Education, Syria,

Barrera-Diaz, C., V. Varela-Guerrero, E. Cuevas-Yanez, G. Martinez-Barrera and G. Roa-Morales et al., 2014. Use of recycled aluminum-polyethylene composite films as anodic electrodes for electrocoagulation of wastewater. Intl. J. Electrochem. Sci., 9: 1034-1043.

Behbahani, M., M.A. Moghaddam and M. Arami, 2011. Techno-economical evaluation of fluoride removal by electrocoagulation process: Optimization through response surface methodology. Desalin., 271 : 209-218.

Berger, K.R., 2002. A Brief History of Packaging. University of Florida, Gainesville, Florida,
Boussu, K., C. Kindts, C. Vandecasteele and B. Van Der Bruggen, 2007. Applicability of nanofiltration in the carwash industry. Sep. Purif. Technol., 54: 139-146.

Chen, G., 2004. Electrochemical technologies in wastewater treatment. Separat. Purific. Technol., 38: $11-41$.

Chisti, M.Y., 1989. Airlift Bioreactors. Vol. 39, Elsevier Applied Science, New York, USA.,.

Di Felice, R., 2005. Liquid circulation rates in two-and three-phase external airlift reactors. Chem. Eng. J., 109: 49-55.

Fajardo, A.S., R.F. Rodrigues, R.C. Martins, L.M. Castro and R.M. Quinta-Ferreira, 2015. Phenolic wastewaters treatment by electrocoagulation process using $\mathrm{Zn}$ anode. Chem. Eng. J., 275: 331-341.

Gonder, Z.B., G. Balcioglu, I. Vergili and Y. Kaya, 2017. Electrochemical treatment of carwash wastewater using $\mathrm{Fe}$ and $\mathrm{Al}$ electrode: Techno-economic analysis and sludge characterization. J. Environ. Manage., 200: 380-390.

Hajjar, S. and N. Farhoud, 2012. [Treatment of Hazardous Waste]. University of Aleppo, Aleppo, Syria, (In Arabic).

Karakulski, K. and A.W. Morawski, 2003. Treatment of wastewater from car washes by ultrafiltration. Fresenius Environ. Bull., 12: 343-348.

Liu, H., X. Zhao and J. Qu, 2010. Electrocoagulation in Water Treatment. In: Electrochemistry for the Environment, Comninellis, C. and G. Chen (Eds.). Springer, New York, USA., ISBN:978-0-387-36922-8, pp: 245-262.

Said, O. and C. MikeC, 2011. Kitchen on Fire!: Mastering the Art of Cooking in 12 Weeks (or Less). Da Capo Press, Cambridge, Massachusetts, USA., ISBN-13:978-0738214535, Pages: 464.

Wang, L.K., Y.T. Hung and N.K. Shammas, 2007. Advanced Physicochemical Treatment Technologies. Humana Press, New York City, New York, USA., ISBN:9781597451734, Pages: 710. 